\title{
ॠUSGS
}

science for a changing world

In cooperation with the Illinois Department of Natural Resources-Office of Water Resources

\section{Manning's Roughness Coefficients for Illinois Streams}
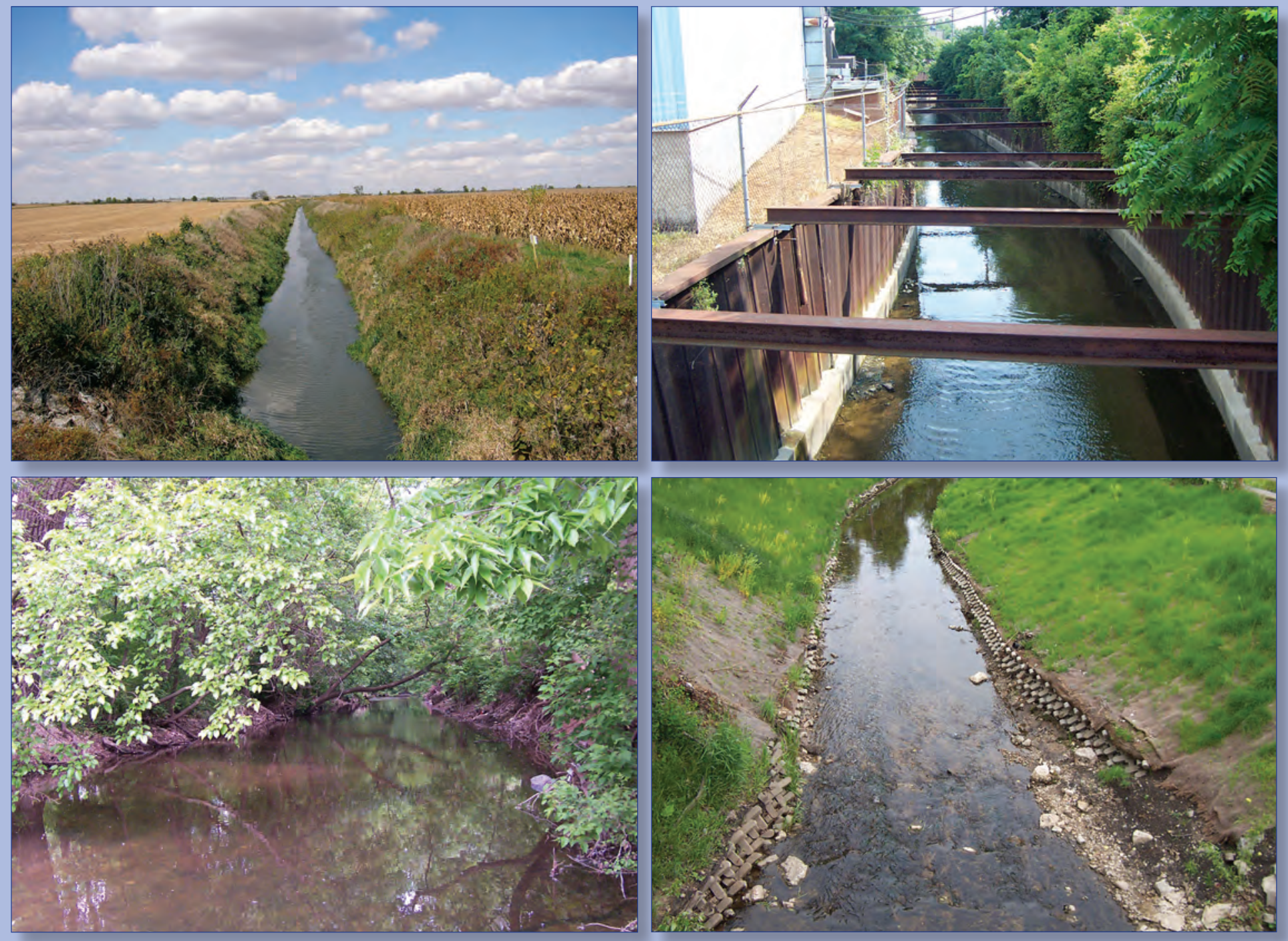

Data Series 668

U.S. Department of the Interior

U.S. Geological Survey 



\section{Manning's Roughness Coefficients for Illinois Streams}

By David T. Soong, Crystal D. Prater, and Teresa M. Halfar, and Loren A. Wobig

Prepared in cooperation with the Illinois Department of Natural Resources-Office of Water Resources

Data Series 668

U.S. Department of the Interior

U.S. Geological Survey 


\title{
U.S. Department of the Interior \\ KEN SALAZAR, Secretary \\ U.S. Geological Survey \\ Marcia K. McNutt, Director
}

\section{U.S. Geological Survey, Reston, Virginia 2012}

\author{
For more information on the USGS - the Federal source for science about the Earth, its natural and living resources, \\ natural hazards, and the environment, visit http://www.usgs.gov or call 1-888-ASK-USGS \\ For an overview of USGS information products, including maps, imagery, and publications, \\ visit http://www.usgs.gov/pubprod \\ To order this and other USGS information products, visit http://store.usgs.gov
}

Any use of trade, product, or firm names is for descriptive purposes only and does not imply endorsement by the U.S. Government.

Although this report is in the public domain, permission must be secured from the individual copyright owners to reproduce any copyrighted materials contained within this report.

Suggested citation:

Soong, David T., Prater, Crystal D., Halfar, Teresa M., and Wobig, Loren A., 2012, Manning's roughness coefficient for Illinois streams: U.S. Geological Survey Data Series 668, 14 p. 


\section{Contents}

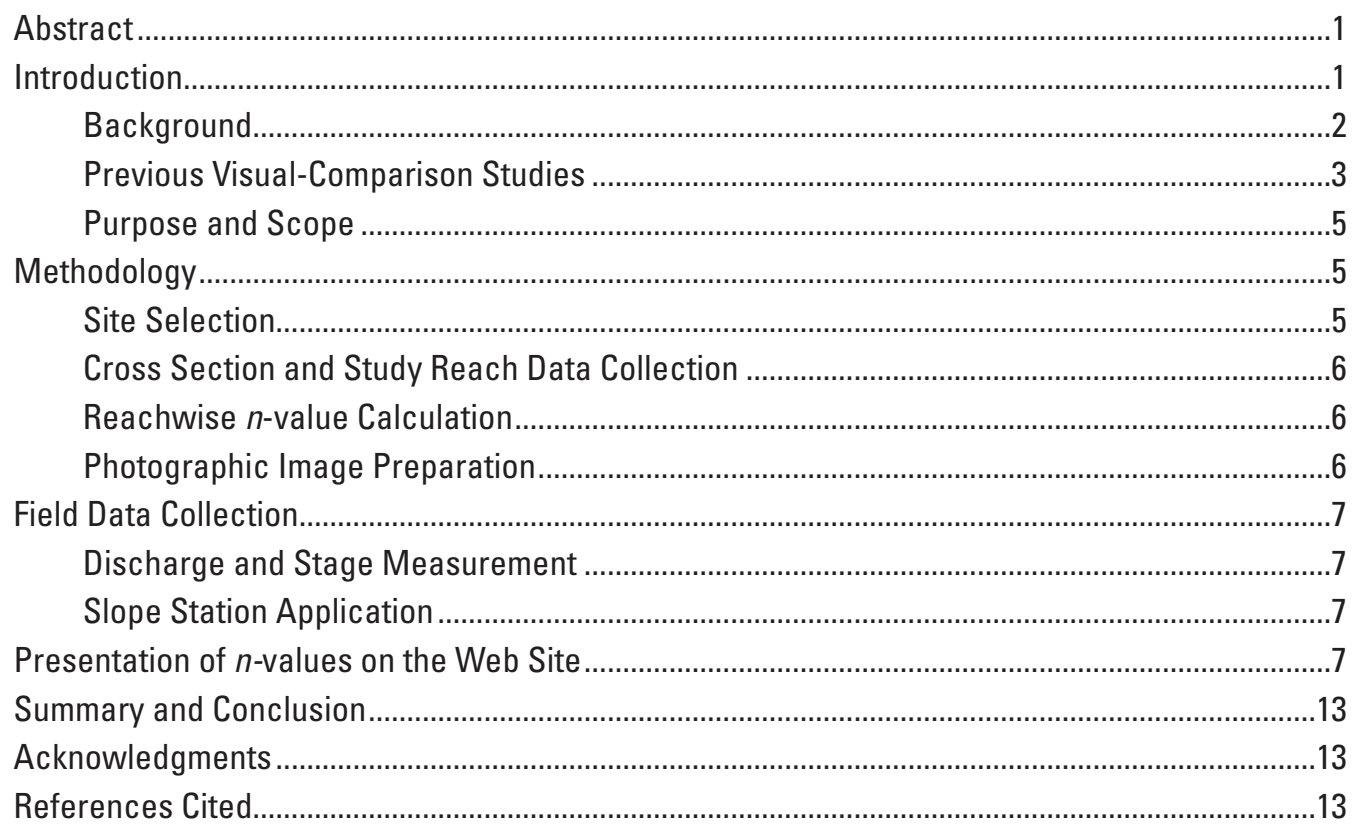

\section{Figures}

1. Variation of Manning's $n$ at different river discharges, Boneyard Creek at Lincoln Avenue at Urbana, III.........................................................................................

2. Variation of Manning's $n$ at different river discharges,

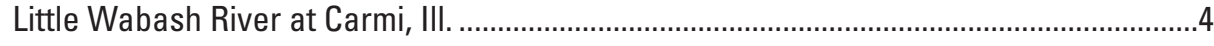

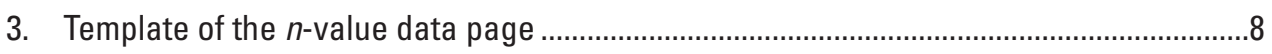

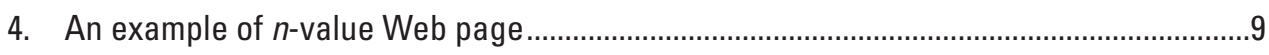




\section{Conversion Factors and Vertical Datums}

\begin{tabular}{|c|c|c|}
\hline Multiply & By & To obtain \\
\hline & Length & \\
\hline foot $(\mathrm{ft})$ & 0.3048 & meter $(\mathrm{m})$ \\
\hline \multirow[t]{2}{*}{ mile (mi) } & 1.609 & kilometer $(\mathrm{km})$ \\
\hline & Area & \\
\hline square foot $\left(\mathrm{ft}^{2}\right)$ & 0.09290 & square meter $\left(\mathrm{m}^{2}\right)$ \\
\hline \multirow[t]{2}{*}{ square mile $\left(\mathrm{mi}^{2}\right)$} & 2.590 & square kilometer $\left(\mathrm{km}^{2}\right)$ \\
\hline & Volume & \\
\hline \multirow[t]{2}{*}{ cubic foot $\left(\mathrm{ft}^{3}\right)$} & 0.02832 & cubic meter $\left(\mathrm{m}^{3}\right)$ \\
\hline & Flow rate & \\
\hline cubic foot per second $\left(\mathrm{ft}^{3} / \mathrm{s}\right)$ & 0.02832 & cubic meter per second $\left(\mathrm{m}^{3} / \mathrm{s}\right)$ \\
\hline
\end{tabular}

SI to Inch/Pound

\begin{tabular}{ccc}
\hline Multiply & By & To obtain \\
\hline Flow rate & \\
\hline meter per second $(\mathrm{m} / \mathrm{s})$ & 3.281 & foot per second (ft/s) \\
\hline
\end{tabular}

Vertical coordinate information is referenced to the National Geodetic Vertical Datum of 1929 (NGVD 29) or the North American Vertical Datum of 1988 (NAVD 88).

Horizontal coordinate information is referenced to the North American Datum of 1983 (NAD 83). 


\title{
Manning's Roughness Coefficients for Illinois Streams
}

\author{
By David T. Soong', Crystal D. Prater', and Teresa M. Halfar', and Loren A. Wobig²
}

\begin{abstract}
Manning's roughness coefficients for 43 natural and constructed streams in Illinois are reported and displayed on a U.S. Geological Survey Web site. At a majority of the sites, discharge and stage were measured, and corresponding Manning's coefficients - the $n$-values - were determined at more than one river discharge. The $n$-values discussed in this report are computed from data representing the stream reach studied and, therefore, are reachwise values. Presentation of the resulting $n$-values takes a visual-comparison approach similar to the previously published Barnes report (1967), in which photographs of channel conditions, description of the site, and the resulting $n$-values are organized for each site. The Web site where the data can be accessed and are displayed is at URL http://il.water. usgs.gov/proj/nvalues/.
\end{abstract}

\section{Introduction}

Accurately calculated stages and discharges at critical reaches of open channels, both natural streams and fabricated canals, are essential to water-resources planning and hydraulic structure design. Studies have shown that the errors in computed water-surface profiles increase significantly with decreased reliability of Manning's coefficient (Burnham and Davis, 1986). At present, however, determining the roughness value for a channel still involves professional judgment, despite advances in analytical and measurement techniques. The application of judgment in estimating roughness values requires prior knowledge or information from existing data and the ability to draw connections between sites. Several helpful databases are available; for example, tabulation of roughness coefficients by Scobey (1933), Chow (1959), and Yen (1991); and photographs of channels with determined Manning's roughness coefficients (the $n$-values) by Chow (1959), Barnes (1967), Hicks and Mason (1998), and others. On the other hand, quantitative methods for estimating roughness values are rare or are approximate in nature. Cowan's adjustment factors (Cowan, 1956) are examples of approximate values. Acquiring the range of roughness values reasonable for the targeted channel reach is useful in practical applications not only for calibration of hydraulic models or permitting processes, but also for the potential prevention of the inadvertent use of the roughness coefficient as a surrogate for possible flaws in the modeling.

The U.S. Geological Survey (USGS) and the Illinois Department of Natural Resources-Office of Water Resources (IDNR-OWR) conducted a study to collect channel characteristic and streamflow data needed to compute the Manning's $n$-values representing a range of common streams in Illinois and to present the computed $n$-values using a system that is readily available and easy to use. For the latter objective, the study adopts the visual-comparison approach similar to the Barnes report (Barnes, 1967), and includes enhanced site descriptions to assist the determination of $n$-values.

\footnotetext{
${ }^{1}$ U.S. Geological Survey, Urbana, Illinois

${ }^{2}$ Office of Water Resources, Illinois Department of Natural Resources, Springfield, Illinois
} 


\section{Background}

The well-known Manning's equation relates flow velocity $(V)$, the friction slope $(S)$, and hydraulic radius $(R)$ through the Manning's roughness coefficient. The equation can be written as:

$$
V=\frac{k_{n}}{n} R^{2 / 3} S^{1 / 2}
$$

where the $k_{n}$ is a constant, $k_{n}=1$ for $V$ and $R$ in SI units (in meters per second and meters, respectively); or 1.486 for $V$ and $R$ in English units (Chou, 1959; Readers are also suggested to review Yen, 1991 for unit of the $k_{n}$ ). An $n$-value can be determined after the $V, R$, and $S$ are known. From field measurement, the $R$ and $V$ terms can be obtained as $R=A / P$, and $V=Q / A$, where $A$ is the submerged area, $P$ is the corresponding wetted perimeter, and $Q$ is the crosssectional discharge. The friction slope, which accounts for only the shear resistance from the wetted perimeter, has to be approximated by other slope terms, and the energy or momentum head gradient, the water-surface slope, and bed slope are feasible candidates. Water-surface slope can be measured in the field and synchronized in time with the velocity or discharge measurement; however, the state of flow needs to be steady and uniform when the bed, watersurface, and energy or momentum head gradients are assumed equal. The same requirements are also necessary for the $V$ and $R$ computations, and such requirements generally are not easily attainable in field conditions. An alternative method for computing the $n$-values is adopted in this report. Equation 2 (for example, Barnes, 1967; Jarrett and Petsch, 1985) is based on the energy equation, applicable to slightly nonuniform reaches, but this equation requires that the flow is steady during the measurement and the energy losses are due only to boundary friction. For a reach having multiple measured cross sections, designated as $1,2, \ldots M-1, M$, where $M$ is the number of cross sections, the equation is:

$$
n=\frac{1.486}{Q} \sqrt{\frac{\left(h+h_{v}\right)_{1}-\left(h+h_{v}\right)_{M}-\left[\left(k \Delta h_{v}\right)_{1,2}+\left(k \Delta h_{v}\right)_{2,3}+\ldots+\left(k \Delta h_{v}\right)_{(M-1), M}\right]}{\frac{L_{1,2}}{Z_{1} Z_{2}}+\frac{L_{2,3}}{Z_{2} Z_{3}}+\ldots+\frac{L_{(M-1) M}}{Z_{(M-1)} Z_{M}}}},
$$

where

$$
\begin{aligned}
Q= & \text { measured discharge, } \\
h= & \text { elevation of the water surface at the respective sections above the datum, } \\
h_{v}= & \text { velocity head at the respective section, which is equal to } \alpha v^{2} / 2 g ; \text { the velocity head coefficient, } \alpha, \\
& \text { is always set to be } 1.0, \\
\Delta h_{v}= & \text { upstream velocity head minus the downstream velocity head, } \\
k\left(\Delta h_{v}\right)= & \text { energy loss because of acceleration of velocity or deceleration of velocity in a contracting or } \\
& \quad \text { expanding reach, } \\
k= & \text { a coefficient, set to zero for contracting reaches and } 0.5 \text { for expanding reaches, } \\
L= & \text { distance between consecutive cross sections, and, } \\
Z= & A R^{2 / 3}, \text { in which } A \text { is the submerged cross sectional area and } R \text { is the hydraulic radius of each cross } \\
& \text { section. }
\end{aligned}
$$

The resulting $n$-values are reachwise $n$-values because the properties of the reach are considered, and equation 2 is expressed in English units. 
Although variables that affect the $n$-values are well described in equations 1 and 2, engineers cannot easily extract from the equations the information content needed for estimating $n$-values at other sites. These variables are affected by other physical factors and processes derived from fluid mechanics (Yen, 2002, 1991). If these physical factors and processes are organized as the roughness characteristics and presented with the site photographs, then more suitable approaches for the visual-comparison method can be developed.

Size and type of the bed and bank materials, shape of the cross section, and longitudinal variation in crosssectional shapes were given in the site descriptions by Barnes (1967) and Hicks and Mason (1998). Other roughness characteristics that can be considered include the distribution of roughness materials along the wetted perimeter, longitudinal bed profile (form resistance), and state of the flow motion such as unsteadiness, viscous friction, and free surface (Rouse, 1965; Henderson, 1966; Yen, 1991, 2002). The adjustment factors organized by Cowan (1956) are examples for organizing the roughness characteristics. A brief description of Cowan's method is as follows:

$$
n=\left(n_{0}+n_{1}+n_{2}+n_{3}+n_{4}\right) m_{5}
$$

where
$n_{0} \quad$ is a basic $n$-value for a straight, uniform, smooth channel,
$n_{1} \quad$ is the adjustment factor for the effect of surface irregularity,
$n_{2}$ is the adjustment factor for the effect of variation in shape and size of the channel cross section,
$n_{3}$ is the adjustment factor for obstruction,
$n_{4} \quad$ is the adjustment factor for vegetation, and
$m_{5}$ is a correction factor for meandering channels.

Magnitudes of various classified groups with examples (descriptions) have been given for each adjustment factor (Cowan, 1956). By including common roughness characteristics observed during measurements, we can enhance our understanding of the $n$-values for the site, and familiarity with these roughness characteristics will improve our ability to estimate $n$-values for other channels.

Variations of $n$-values with discharge or stage (figure 1.1 in Chow, 1959) complicate presentation using the visual-comparison approach. This project collected data at different discharges (stages) for a majority of its study sites and presented the determined $n$-values and photographs at the time of data collection (see "Presentation of $\mathrm{n}$-Values on the Web Site"). For those sites for which multiple $n$-values are available, plots like figures 1 and 2 below and the description of bed and bank materials can be useful in understanding the patterns of variations. For additional information, Yen (2002) has theoretically illustrated such changes by considering factors in composite roughness (variation in $n$-values along the wetted parameter) in simple channel shapes and compound channels (main channel and floodplain with combinations in roughness). Figure 1 is a plot of $n$-values against discharge at Boneyard Creek at Lincoln Avenue at Urbana (station 03337100). A best-fit line was added to the figure only for illustrating a general pattern of the variation. The Lincoln Avenue site is characterized by a reworked narrow trapezoidal channel with bed width at approximately 20 feet (ft). Vegetation on the bed is the dominant roughness feature and concrete blocks pave both banks. Because the roughness value for concrete blocks is less than that of vegetation, the observed (composite) $n$-value decreases as discharge increases when more concrete blocks become submerged and the effect of vegetation on the bed decreases. In contrast, the Little Wabash River at Carmi site (station 03381500) is a natural channel, having mild bank slope and the channel width is greater than $200 \mathrm{ft}$. Bed materials consist of smooth rock and gravels, free of vegetation, and bank materials are clay and sand mixtures, sparsely covered with exposed treeroots, brush, and weeds. As discharge and stage increase, more roughness materials were included in the submerged area and the $n$-values increase (fig. 2). 


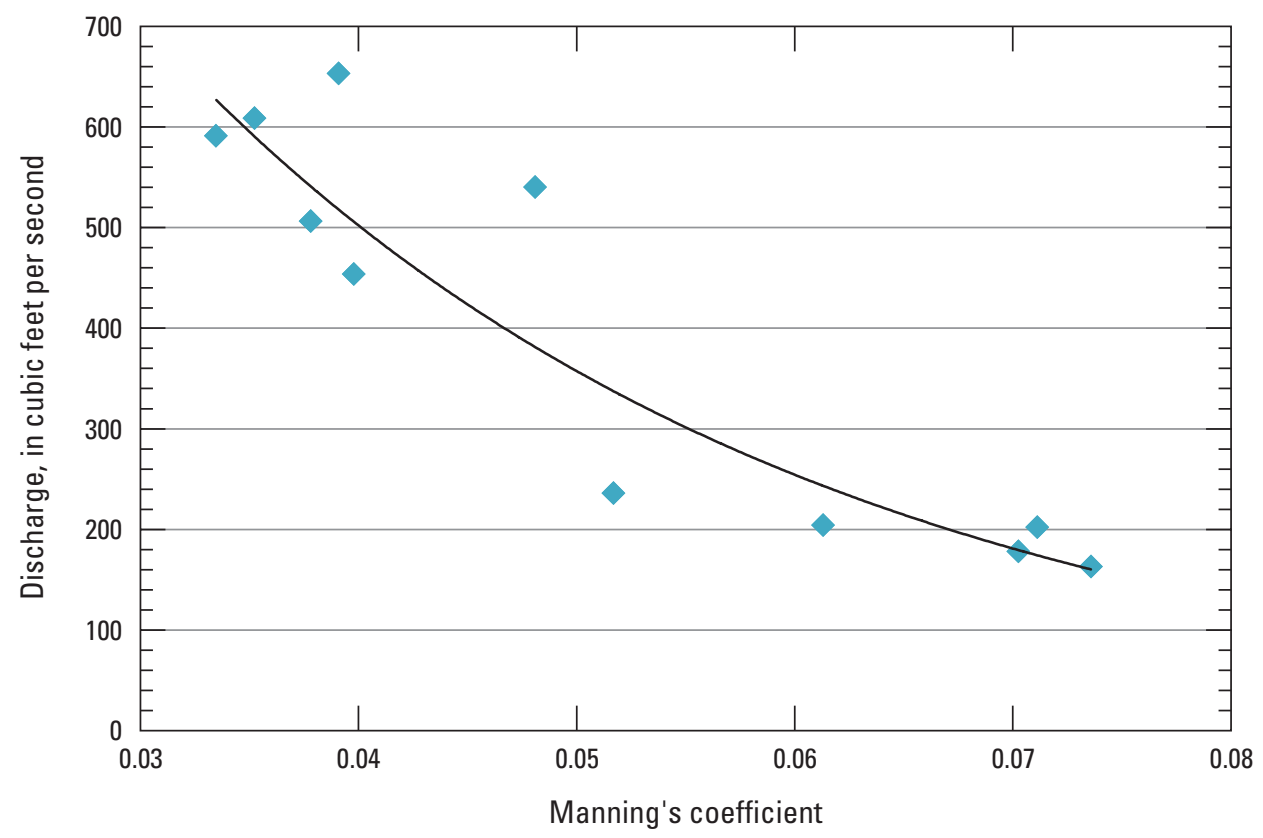

Figure 1. Variation of Manning's $n$ at different river discharges, Boneyard Creek at Lincoln Avenue at Urbana, III.

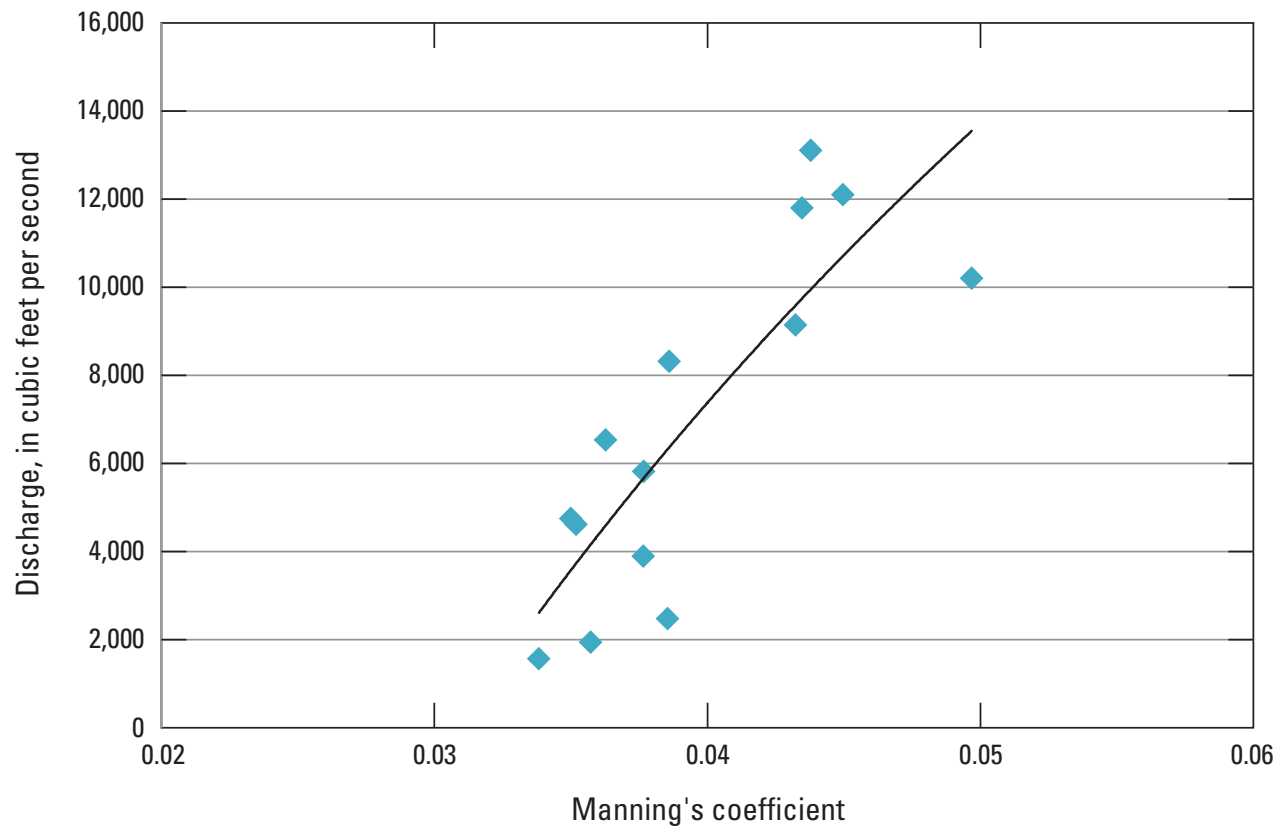

Figure 2. Variation of Manning's $n$ at different river discharges, Little Wabash River at Carmi, III. 


\section{Previous Visual-Comparison Studies}

Pictures and concise descriptions of typical $n$-values for various types of channels were presented by Chow (1959) as a method for estimating $n$-values at similar channels. For irrigation channels, Fasken (1963) compiled the Kutter's $n$-values (Chow, 1959) with data from sites across the United States. To assist in identifying the similarities in roughness factors, Fasken (1963) also adopted the visual approach by providing photographs of low-flow conditions and describing the channels. By characterizing the roughness factors according to the channel geometry, appearance, and roughness materials, engineers are able to improve the ability to select roughness coefficients for their channels from a broad database. Barnes published $n$-values for 50 streams in the United States, along with color photographs, sketches of the cross sections, and descriptions of the sites (Barnes, 1967). The reported $n$-values were computed with data collected after major floods at locations where channels were stable, and photographs of the reach represented the conditions immediately after the flood. In computing $n$-values, Barnes applied an equation (presented as equation 2) that is suitable for slightly nonuniform channels and involves measured stage and geometric data from multiple cross sections; hence, the $n$-values reported in Barnes' report are reachwise-averaged $n$-values. Since its publication, Barnes' report has become widely referenced in practical applications and is recognized as a useful handbook for estimating Manning's $n$-values. However, the need for representative $n$-values for additional channel characteristics has increased with demand for proper water-resources planning and infrastructure design. Examples of studies that meet this need include Hicks and Mason (1998), who present $n$-values for 78 New Zealand streams; Jarrett (1985), for high-gradient streams in Colorado; Arcement and Schneider (1989), for flood plain $n$-values; Gillen (1996), for streams in west-central Florida; Coon (1998), for natural stream channels with vegetated banks; Phillips and Ingersoll (1998), for natural and constructed channels in arid and semiarid environments in Arizona; and Yochum and Bledsoe (2010), for low, mid-, and near-bankfull flows in cascade, step-pool, and plane-bed stream reaches in Fraser Experimental Forest, Colorado.

\section{Purpose and Scope}

This report describes the methods used in site selection, reachwise $n$-value calculation, and photograph image preparation; field data collection of discharge and stage as well as slope-station application; and presentation on a Web site. This Web site has been developed to catalog Manning's roughness coefficient determinations for various types of natural and constructed streams in Illinois. The data reporting follows a template and uses the visual approach similar to that of Barnes (1967), but it includes ancillary information relevant to roughness characteristics. The template and one data presentation example are included in this report.

Data was collected only from in-bank channel flows; collection of flood-plain flows was not covered in the present scope of work. In practical applications, the Manning's roughness coefficients determined in this study are for one-dimensional flow and reachwise values based on the energy approach.

\section{Methodology}

Field sites used for $n$-value collection were selected from river reaches in Illinois. The coverage ranged from small streams to large rivers with drainage areas ranging from less than 50 to greater than 1,000 square miles. Channels were both natural and constructed. Bed and bank characteristics of the sites having natural channels range from fine clay to cobbles. Bed and bank characteristics of sites having constructed channels include such features as sheet piling, laid shale, A-jacks, lunker boxes, rip-rap, and gabion boxes. When conditions were feasible, multiple data points were collected during various stages (or discharges) for presenting the variations in $n$-values with changes in the inclusion of submerged bank materials and other factors. 


\section{Site Selection}

Study sites were selected to cover variations in channel bed and bank materials, stream sizes (represented by drainage areas), and stream geomorphologic characteristics. A planning matrix, based on natural and constructed bed and bank materials and drainage areas, was developed for guiding the site selection and tracking data collection. Constructed beds and banks are becoming more common in urban environments, so estimation of $n$-values for these types of streams was included. During the selection process, USGS streamflow-gaging stations were screened first, because site information for them was available. Additional sites that represent roughness characteristics not covered by these USGS gage sites were determined based on prior field information and through site inspection, with focus on sites of interest in IDNR-OWR projects. The final site selection also depended on how well the selected roughness characteristics were represented in the reach; the longitudinal variations in cross sections, excluding those that had abrupt contraction or expansion variations or both; the absence of lateral inflows, free from backwater effects; and accessibility and feasibility for measuring water-surface slopes and discharges at low and high stages in the study reach. Data collection and in-office processing procedures are described below. One exception is that five of the selected USGS sites were slope stations. For these stations, data were retrieved from past records, and the procedures are explained in the "Slope Station Application" section.

\section{Cross Section and Study Reach Data Collection}

Cross sections were used for describing geometric features and their longitudinal variations in each study reach. Hydraulic properties such as submerged area, hydraulic radius, and wetted perimeter were also computed from the given cross-sectional data. Hence, field surveys were conducted when possible to obtain the cross sections used in the study. However, recently conducted hydraulic modeling studies were also a viable source of cross sections. At least three cross sections were used for describing a study reach if the reach was reasonably straight and uniform; additional cross sections were added for tracking variations in more complicated reaches. The length between each cross section was measured in the field. The extent of a study reach was determined based on the coverage of the roughness characteristics, the absence of sewer inflows and obstacles, and adequate water-surface slope that could be measured in the study reach.

\section{Reachwise n-value Calculation}

The reachwise $n$-values are computed using equation 2 described above. After the discharge at one cross section and water-surface elevations at multiple cross sections were measured, a Hydrologic Engineering Center's River Analysis System (HEC-RAS) (Hydrologic Engineering Center, 2011) model was set up and adjusted to agree with the water-surface elevations during the $n$-value survey. The velocity and energy heads at each section of the HECRAS model were then used to approximate these hydraulic properties in equation 2 . The $n$-values computed from equation 2 were reported as the final reachwise $n$-values of the site. Also reported as the reachwise data are the mean values of the hydraulic properties for all cross sections used in each study reach (fig. 4).

\section{Photographic Image Preparation}

Four types of images were prepared for presenting the field data (figs. 3 and 4) on the Web site:

1. the location of the study site identified on a USGS quadrangle map,

2. an aerial map of the study site for illustrating the characteristics of the study reach,

3. plots of selected cross sections for viewing the uniformity or changes in geometric factors,

4. and reach photographs showing the conditions for which an $n$-value was calculated. 
Locations of the cross sections were identified on the aerial photograph. Photographs of the channel were taken at the time of $n$-value survey and included low flow conditions to illustrate the bed and bank materials and medium and high flow conditions to show the flow and channel conditions. These site photographs were annotated with site name, view direction, date, flow conditions, and the computed $n$-value.

\section{Field Data Collection}

\section{Discharge and Stage Measurement}

Discharge was measured at a predetermined cross section during each storm event by using either current meters, following standard methods (Rantz and others, 1982), or acoustic Doppler current profilers (ADCP) (Simpson, 2001). Water-surface elevations were measured at the upstream and downstream ends as well as at the discharge site for each $n$-value survey. The following equipment was used for measuring the water-surface elevations (stages):

1. a steel tape measure weighted down to the water surface from a known elevation at permanent upstream and downstream reference points,

2. a wire-weight gage (WWG), or

3. preinstalled vertical staff gages.

All of the instruments used have the same reading interval of $0.01 \mathrm{ft}$. Stage readings were recorded with synchronized watches for the entire $n$-value survey. These discrete stage readings were then converted to elevations above NGVD or NAVD, depending on the datum used at the gage, and plotted as a function of time for estimating stage drop during the same period. For some events when only discharges were measured because of on-site logistic requirements, corresponding stages were noted during the discharge measurement and surveyed at a later date.

\section{Slope Station Application}

Records of stage and discharge measurements from five slope-stations on the Illinois, Sangamon, and Big Muddy Rivers were reviewed, and events suitable for the analysis of $n$-values were retrieved. Slope stations (Rantz and others, 1982) are used at river reaches where variable backwater or looped ratings exist. At slope stations, an auxiliary gage is operated in conjunction with the base gage and is located upstream or downstream of it. The stage recording at the base and auxiliary stations is synchronized, and the distance between the main and auxiliary gages is determined to minimize errors in computing the fall (Rantz and others, 1982). The events selected for $n$-value calculation were high-flow events at near bank-full conditions, the reaches had adequate surface drops, and stages at downstream stations were low (no backwater).

\section{Presentation of $n$-values on the Web Site}

Manning's $n$-values from 43 Illinois steam reaches are presented on the Web site at http://il.water.usgs.gov/ proj/nvalues/. Users can find information on $n$-values for individual sites through the "Site Descriptions" link. The Web site allows users to compare data through a searchable database and to interactively enter variables into various hydraulic equations to solve for the unknowns. For example, users can search for sites by either specifying the range of $n$-values of interest or using bed and bank characteristics. The "Calculate $n$-values" link helps users compute $n$-values through a list of equations, if they have obtained the hydraulic and geometric data of a site. If the users wish to compare the calculated values to sites with the same or similar values, they can select the "Similar $n$-values" button.

Figure 3 shows a presentation template of $n$-values for Illinois streams, and figure 4 shows an example $n$-value Web presentation. 


\section{Study Reach}

Location map: the study reach is identified with a red box on the USGS quadrangle map.
Aerial photographs overlaid with cross sections used in the $n$-value computations displayed with cross section identification numbers.

Plots of representative cross sections for illustrating the geometric features of the channel in the n-value study. These plots were generated by a HEC-RAS model developed for the site and adopted the HEC-RAS annotations. For each cross-sectional plot the station ( $x$-axis) and elevation (y-axis) pairs are shown as black dots, the red dots are designated bank points, and the n-value may change outside the bank points. Each cross-section is identified with the station identification number shown on top.

Study Reach. - Describes in more detail the location, length, and other characteristics.

Gage Location. - If a permanent USGS streamflow-gaging station is nearby, description of station location is given.

Drainage Area.- The drainage area above the streamflow station, or above the downstream end of the study reach, is given.

Gage Datum and Elevation of Reference Points. - Specifics that the gage datum is in either NGVD 29 or NAVD 88 , and describes other reference points used in field data-collection activities. Other reference points include tapedown points, staff gages, and wire-weight gages.

Stage and Discharge Measurement. - This section describes how water surface elevations (and therefore slope) and discharges are measured in the study reach.

n-value Table. - The n-values, the date of data collection, discharge, and associated hydraulic parameters are listed in ascending order by discharge. (Note that the $n$-value and hydraulic parameters are reachwise-averaged data.)

Field photographs taken at the time of measurement have the corresponding n-value marked. Photographs are in order from low to high flows (photograph presentation continues)

Description of the Channel. - Describes the common factors that canm be identified in the field in the following sequence.

- A general assessment of the channel (natural, man-made, urban, and others)

- Bed: material (describe variation in particle size or bed material across the channel)

- Bank: material (describe variation in particle size or bank material distribution on both banks)

- Geometry: heights, widths, bank slope, geometric shape, and others

- Channel obstruction: algae, logs, debris, structure and others

- Geomorphologic parameters: uniformity in cross sections, riffle-and-pool structures, straight or meandering.

Figure 3. Template of the $n$-value data page. 


\section{Middle Fork Vermilion River Above Oakwood, IL}
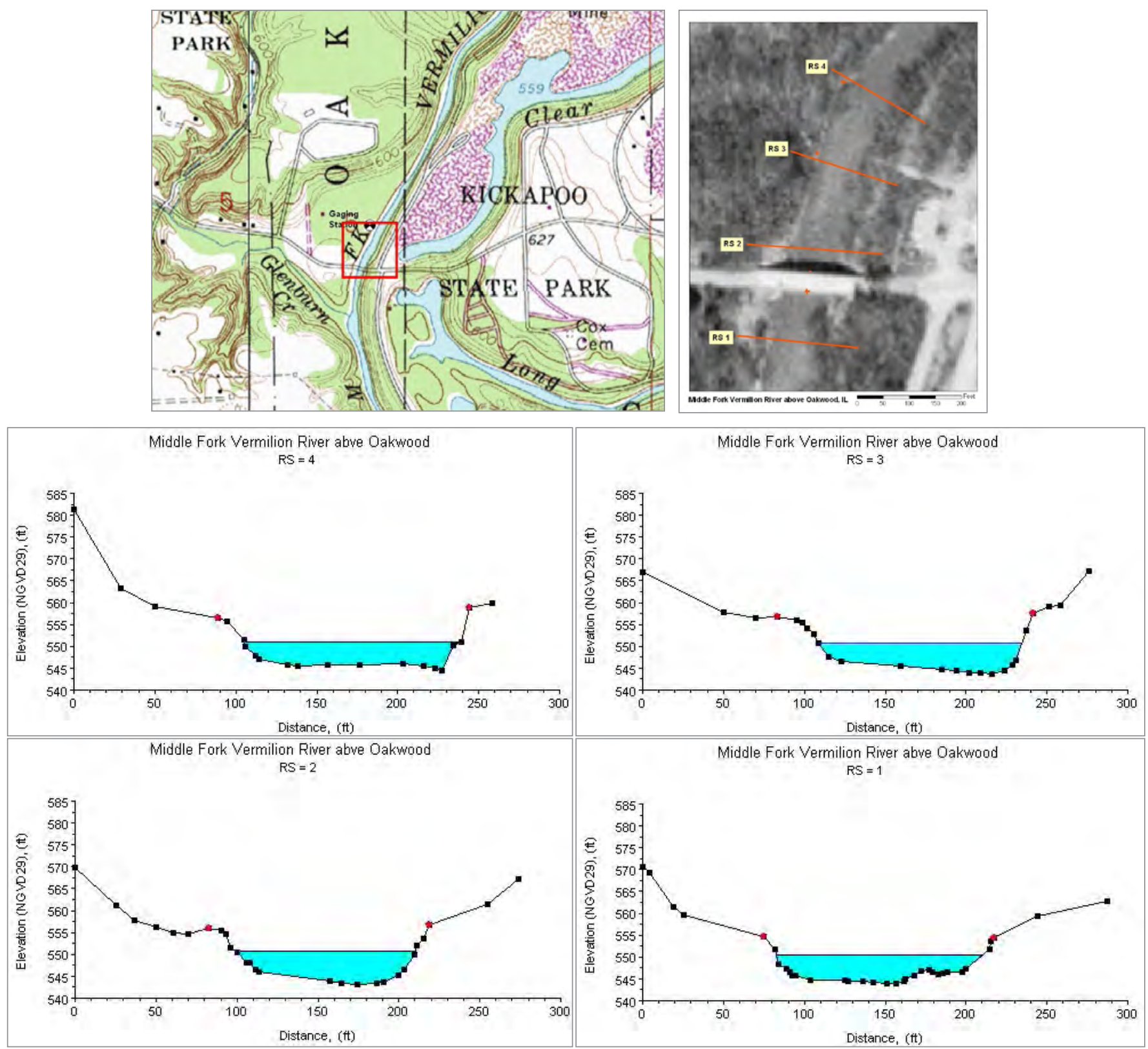

Study Reach. - The channel reach is natural. The study reach is approximately $400 \mathrm{ft}$ long and is adjacent to the Kickapoo State Park Road Bridge, as shown in the quadrangle map on the top left. The reach starts from $100 \mathrm{ft}$ downstream of the Kickapoo State Park Road bridge and extends approximately $300 \mathrm{ft}$ upstream. There are four surveyed cross sections (Surveyed by the U.S. Geological Survey in May 2003) available for describing channel geometries in the study reach (see plots above). The channel alignment, approximate variations in the channel width and bank conditions, and locations of the cross sections are shown in the aerial photograph on the top right. Cross sectional geometries vary gradually from upstream to downstream.

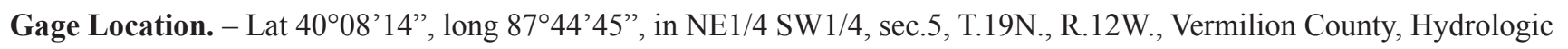
Unit 05120109, on the right bank $150 \mathrm{ft}$ upstream from the Kickapoo State Park Road bridge, 1.0 mi upstream from the Interstate Hwy 74 bridge, 2.0 mi northeast of Oakwood, and at river mi 31.7. The USGS streamgage station number is 03336645.

Figure 4. An example of $n$-value Web page. 
Drainage Area.- 432 sq mi.

Gage Datum and Elevation of Reference Points. - Datum of the gage is $544.42 \mathrm{ft}$. Staff gage 1 is located $300 \mathrm{ft}$ upstream from the bridge on the right bank, elevation of the brass screw on the staff $=549.664 \mathrm{ft}$. Staff gage 2 is located $150 \mathrm{ft}$ upstream from the bridge on the right bank, elevation of the brass screw on the staff $=549.446 \mathrm{ft}$. A reference point created for the $n$-value study, RP-N1, is the top of the nut on the concrete anchor on the upstream side of the bridge at midchannel near station 90, elevation $=570.508 \mathrm{ft}$. A wire-weight gage $(\mathrm{WWG})$ is attached to the downstream face of the Park Road bridge. All elevations are referenced to NGVD29.

Stage and Discharge Measurement, and Computed $\boldsymbol{n}$-Values. - Water-surface elevations were read from the two staff gages at the upstream portion of the study reach, RP-N1 on the upstream side of the bridge and the WWG before, during, and after each discharge measurement. Stage readings from the gage house also were referenced for checking the readings. Discharge measurements were made using the conventional current-meter method. The computed $n$-values are listed in the following table. Whenever possible, the computed n-values are associated with a photograph taken at the time of the measurement. The photographs are arranged from low to high discharge in order to illustrate the contributing factors of $n$-values at a particular discharge.

\begin{tabular}{|c|c|c|c|c|c|c|}
\hline $\begin{array}{c}\text { Date of } \\
\text { Observation }\end{array}$ & $\begin{array}{c}\text { Average } \\
\text { Discharge } \\
\left(\mathbf{f t}^{3} / \mathbf{s}\right)\end{array}$ & $\begin{array}{c}\text { Cross } \\
\text { Section } \\
\left.\text { Area (ft } \mathbf{~}^{2}\right)\end{array}$ & $\begin{array}{c}\text { Hydraulic } \\
\text { Radius (ft) }\end{array}$ & $\begin{array}{c}\text { Mean } \\
\text { Velocity } \\
(\mathbf{f t} / \mathbf{s})\end{array}$ & $\begin{array}{c}\text { Coefficient } \\
\text { of } \\
\text { Roughness } \\
\boldsymbol{n}\end{array}$ \\
\hline $4 / 25 / 2003$ & 148.0 & 128.1 & 1.49 & 1.19 & 0.002240 & 0.025 \\
\hline $5 / 15 / 2003$ & 565.0 & 220.5 & 2.06 & 2.61 & 0.000560 & 0.023 \\
\hline $6 / 12 / 2003$ & 3070.0 & 604.0 & 4.80 & 5.10 & 0.000769 & 0.033 \\
\hline $3 / 29 / 2004$ & 3380.0 & 647.8 & 5.08 & 5.23 & 0.000769 & $\mathbf{0 . 0 3 1}$ \\
\hline
\end{tabular}
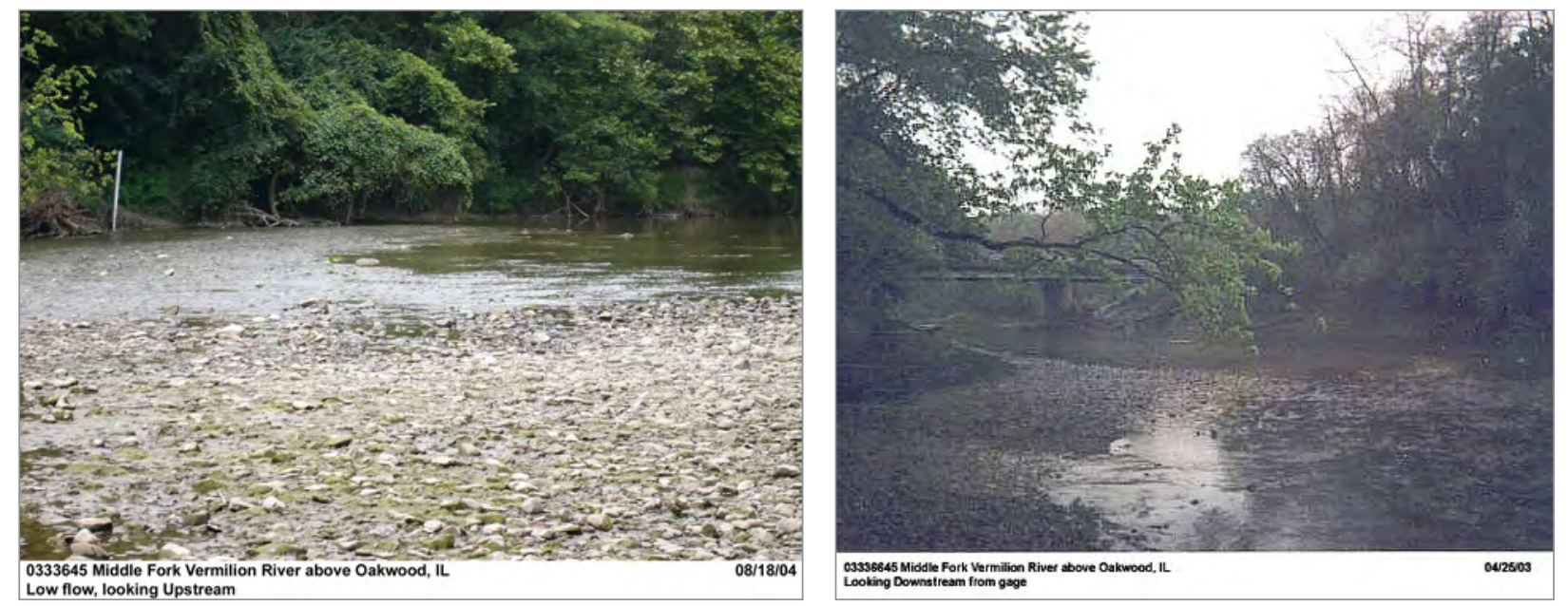

Figure 4 (continued). An example of $n$-value Web page. 

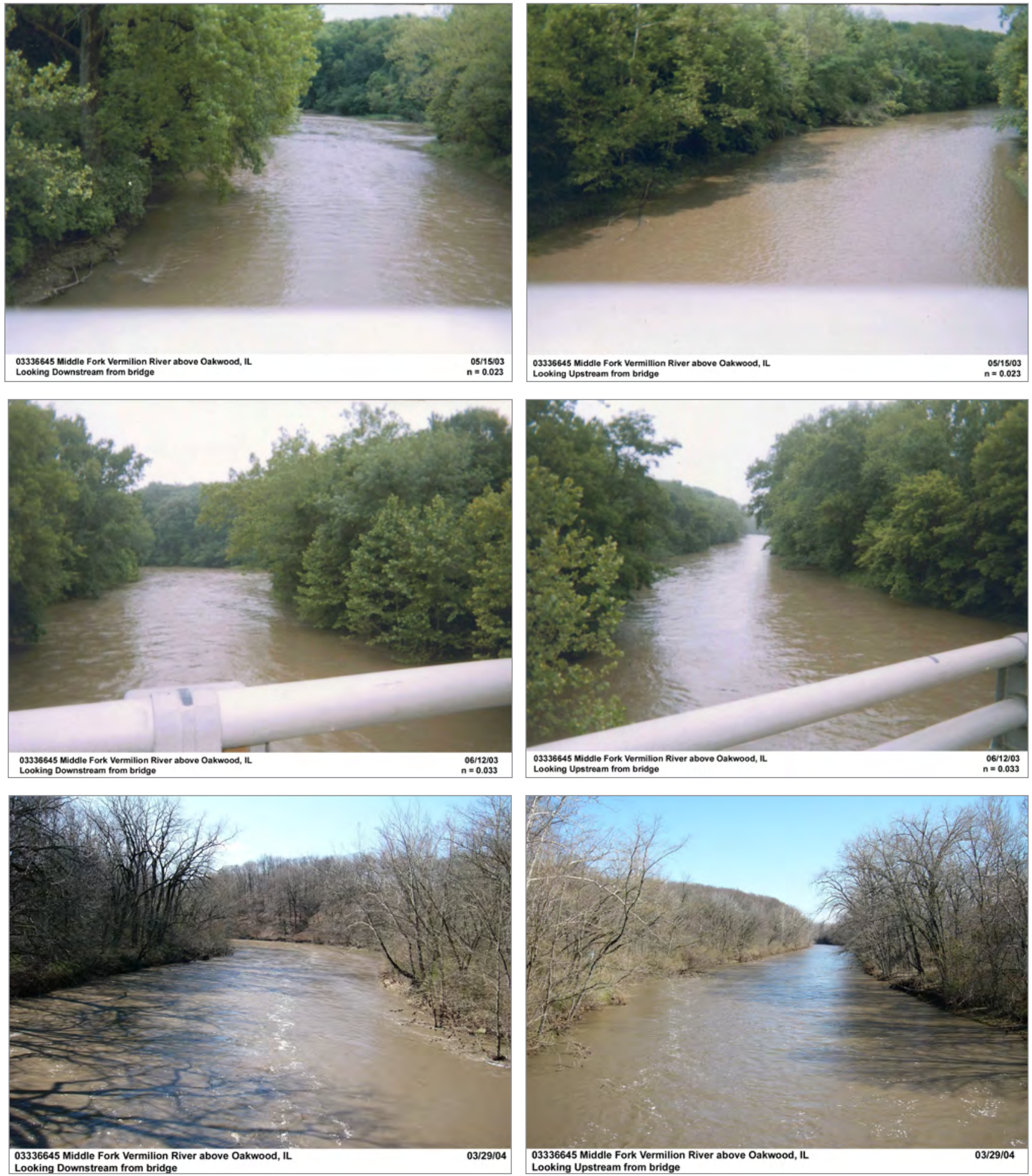

Figure 4 (continued). An example of $n$-value Web page. 


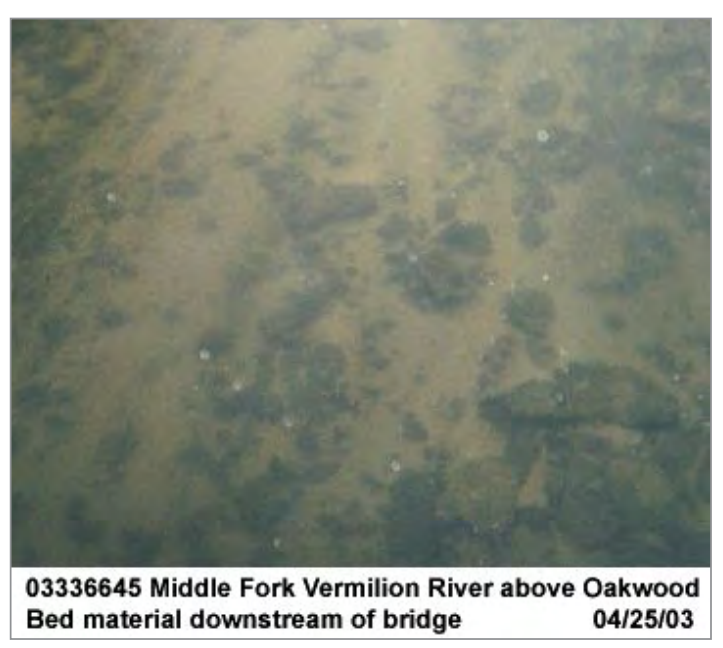

Description of the Channel. - This channel is natural. The streambed consists primarily of sand, gravel and cobble mixtures from the upstream end to downstream of staff gage 2 and RP-N1. Downstream from RP-N1, the streambed consists of bedrock and scattered boulders to the end of the reach. The bottom width of the channel varies between 100 and $120 \mathrm{ft}$. The channel is trapezoidal and subject to debris accumulation at the bridge on the right side of the channel. The banks are. about $13 \mathrm{ft}$ high and have a top width between 135 and $160 \mathrm{ft}$. Banks are steep with alluvial sand deposits at toe, slightly eroded surfaces, and patches of bushes and tall trees on top of the banks. The study reach is fairly straight.

Floods. - Maximum discharge, 15,500 ft³/s, Apr. 13, 1994, gage height, $20.46 \mathrm{ft}$.

Figure 4 (continued). An example of $n$-value Web page. 


\section{Summary and Conclusion}

This report describes the background and underlying methodology for the interactive Web site presenting Manning's $n$-values for 43 Illinois streams. By combining the visual-comparison approach with descriptions of field conditions contributing to flow resistance factors, users are provided with better information for assessing Manning's $n$-values at their sites of interest. Identifying contributing factors to the local roughness coefficient, understanding how $n$-values vary with stage or discharge, and having an approximate base $n$-value for the selected channel are components that can assist users in transferring $n$-values presented in the study sites to other sites.

\section{Acknowledgments}

The study described in this publication was conducted in cooperation with the Illinois Department of Natural Resources-Office of Water Resources. Cross-sectional data and datum were obtained from the Illinois Department of Transportation; the U.S. Army Corps of Engineers, Chicago, Rock Island, and St. Louis Districts; and from municipalities and private consulting firms.

\section{References Cited}

Arcement, G.J., Jr., and Schneider, V.R., 1989, Guide for selecting Manning's roughness coefficients for natural channels and flood plains: U.S. Geological Survey Water-Supply Paper 2339, 38 p.

Barnes, H.H., 1967, Roughness characteristics of natural channels; U.S. Geological Survey Water-Supply Paper $1849,213 \mathrm{p}$.

Burnham M., and Davis, D.W., 1986, Accuracy of computed water surface profiles: U.S. Army Corps of Engineers, Hydrologic Engineering Center, Research document no. 26, 215 p. Accessed July 2011 at http://isddc.dot.gov/ OLPFiles/FHWA/010462.pdf.

Chow, V.T., 1959, Open-channel hydraulics: New York, McGraw-Hill, 680 p.

Coon, W.F., 1998, Estimation of roughness coefficients for natural stream channels with vegetated banks: U.S. Geological Survey Water-Supply Paper 2441, 133 p.

Cowan, W.L., 1956, Estimating hydraulic roughness coefficients: Agricultural Engineering, 377,p. 473-475.

Fasken, G.B., 1963, Guide for selecting roughness coefficient "n” values for channels: U.S. Department of Agriculture, Soil Conservation Service, Lincoln, Nebr., 24 p. plus appendixes.

Gillen, D.F., 1996, Determination of roughness coefficients for streams in West-Central Florida: U.S. Geological Survey Open-File Report 96-226, 93 p.

Henderson, F.M., 1966, Open channel flow: New York, MacMillan Publishing Company, 522 p.

Hicks, D.M., and Mason, P.D., 1998, Roughness characteristics of New Zealand rivers: National Institute of Water and Atmospheric Research Ltd., Water Resources Publications, LLC, 329 p.

Hydrologic Engineering Center, 2011, Hydrologic Engineering Center River Analysis System (HEC-RAS): Hydrologic Engineering Center, U.S. Army Corps of Engineers, Davis, Calif. Available online at http://www.hec.usace. army.mil/software/hec-ras/. (Various versions have been used during the study.)

Jarrett, R.D., 1985, Determination of roughness coefficient in for streams in Colorado: U.S. Geological Survey Water Resources Investigations Report 85-4004, 54 p. 
Jarrett, R.D., and Petsch, H.E., Jr., 1985, Computer program NCALC user's manual—verification of Manning's roughness coefficient in channels: U.S. Geological Survey Water Resources Investigations Report 85-4317, 27 p.

Phillips, J.V., and Ingersoll, T.L., 1998, Verification of roughness coefficients for selected natural and constructed stream channel in Arizona: U.S. Geological Survey Professional Paper 1584, 77 p.

Rantz, S.E., and others, 1982, Measurement and computation of streamflow-Volume 1: Measurement of stage and discharge: U.S. Geological Survey Water-Supply Paper 2175, 284 p. plus an index.

Rouse, H., 1965, Critical analysis of open-channel resistance: Journal of Hydraulic Engineering, American Society of Civil Engineers, v. 91, no. 4, p. 1-25.

Scobey, F.C., 1933, Flow of water in flumes: U.S. Department of Agriculture Technical Bulletin 393, $99 \mathrm{p}$.

Simpson, M.R., 2001, Discharge measurements using a broad-band acoustic doppler current profiler: U.S. Geological Survey Open File Report 01-1, 134 p.

Yen, B.C., 2002, Open channel flow resistance: Journal of Hydraulic Engineering, American Society of Civil Engineers, v. 128, no. 1, p. 20-39.

Yen, B.C., 1991, Hydraulic resistance in open channels, in Yen, B.C., ed., Channel flow: centennial of Manning's formula: Water Resources Publications, Littleton, Colo. p. 1-135.

Yochum, S., and Bledsoe, B., 2010; Flow resistance estimation in high-gradient streams, in Joint Federal Interagency Conference, 2nd, Las Vegas, Nev., June 27-July 1, 2010, available online at http://acwi.gov/sos/pubs/2ndJFIC/ Contents/5E_Yochum_01_04_10_2_.pdf. 



$$
\frac{1}{5}
$$

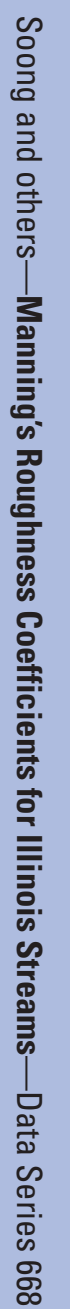

